\title{
Practitioner Article
}

\section{The possible impact of university corruption on customers' ethical standards}

Received (in revised form): 15th August 2011

\section{Merlin Stone}

is Head of Research at The Customer Framework. He is author or co-author of many articles and 30 books on customer management. The UK's Chartered Institute of Marketing listed him in 2003 as one of the world's top 50 marketing thinkers, he was nominated as one of the 20 most influential people in the direct marketing industry in a Precision Marketing readership poll in 2003, while NOP World nominated him in 2004 as one of the 100 most influential individuals for their input and influence on the development and growth of e-commerce and the Internet in the United Kingdom over the previous 10 years. He is a Fellow of the Chartered Institute of Marketing and an Honorary Life Fellow of the UK's Institute of Direct Marketing. He is also on the editorial advisory boards of several academic journals. Parallel to his business career, he has also pursued a full academic career, holding senior posts at various universities. He started his career teaching economics at UMIST (now part of Manchester University), then moved to Kingston Polytechnic, also teaching economics. He then went into the engineering industry, before returning to Kingston to teach marketing and business strategy. Other significant academic posts included being a member of the senior staff at Henley Management College, Professor and then Dean at Kingston University (he was the Dean of Human Sciences, otherwise known as arts and social sciences when it became a university), and Professor at Surrey University and Bristol Business School. He is now a visiting professor at De Montfort, Portsmouth and Oxford Brookes Universities and an Associate Lecturer in Economics at the Open University.

\section{Michael Starkey}

is a Principal Lecturer in Customer Relationship Management (CRM) at De Montfort University. Michael Starkey is one of the UK's top researchers and teachers in this highly specialized subject. He has recently published articles on customer data implications of social media, and other advanced topics in CRM. He is the co-author of three major reports on CRM with Merlin Stone and over 40 articles on CRM. He also has extensive practical experience, having worked in the food industry and precision engineering before joining De Montfort University. He has been engaged recently on an 18-month Knowledge Transfer Partnership programme project (For more on these partnerships, see http://www.ktponline.org.uk/, accessed 12 August 2011) helping an NGO move from relying almost entirely on government funding to becoming self-financing and customer focused. He is on the editorial review boards of this journal. He has also taught CRM for a number of years at the Cass Business School, and to Senior Police officers of Hertfordshire, Norfolk and Suffolk constabularies. He has now retired from most of his academic commitments and is focusing on commercial training and consulting projects in CRM.

\begin{abstract}
This article explores the rapidly rising incidence of corruption and fraud in universities, whether by students or staff. It asks whether companies are prepared for the extent to which their future customers or employees may have been socialised into unethical patterns of behaviour, and outlines an agenda for students to enable them to identify whether they are getting fair value for money and to determine how they should respond in situations where they are not.
\end{abstract}

Journal of Database Marketing \& Customer Strategy Management (2011) 18, 154-170.

doi:10.1057/dbm.2011.18; published online 19 September 2011

Keywords: students; cheating; plagiarism; corruption; fraud; qualifications

Correspondence:

Merlin Stone

The Customer Framework, Lily Hill House, Lily Hill Road, Ascot RG12 2SJ, UK E-mail: merlin.stone@ thecustomerframework.com

\section{INTRODUCTION}

In this unconventional article, we explore a very difficult question - difficult for politicians, business people, students and their parents: If students face increasingly poor quality in higher education, and duplicity in the discourse about the reasons for this poor quality, what will they expect 
of the large organisations that many of them will work for later in life? How will they behave as customers or employees of these organisations, whether in the commercial or public sectors? How should they cope with this when they are students? Will the coping behaviour they learn be transferred to their lives as employees or customers?

We cannot hope to answer all these questions fully in this paper, partly because neither of the authors are experts in the question of academic ethics and quality, though both have been deeply involved in delivery. However, we have examined the literature in depth from the perspective of customer management, and from the perspective of the customers, that is, students. In any case, so much depends on the individual student, and the organisations they work for and buy from. However, particularly in industries and markets where trust is important - whether for employees or customers - it is important for managers to understand what experience their customers or employees might have gone through as students, and how they have been socialised into the world of achievement, appraisal and the relevant ethics.

Put simply, the more the world drives for volume in higher education, the greater the probability that students who pass through higher education institutions will have become at least partly corrupt or fraudulent in order to achieve their financial and educational targets, and the greater the probability that they will have learnt to play a rather dishonest game in order to get the result they need to start their career. This relates closely to one author's earlier work on the issue of good and bad customers, particularly the clear consequences, in terms of reduction of quality in the customer base, of marketing strategies based upon rapid increases in the size of the customer base, and the consequent requirement for strategies required to manage increasing number of bad customers. ${ }^{1-3}$
The idea for this article started with our personal experience as university faculty involved in delivering what we hope is quality education. We experienced many personal frustrations in so doing. When, after moving house, one of the authors, Merlin Stone, registered as a private tutor, as part of a strategy for doing more work locally, he was shocked by the approaches that he received from students - whether at school or university - studying business and economics. With school pupils, the problem was awful tuition, often compounded by teachers putting those they perceived as poorer students under pressure not to take examinations for fear of reducing the school's grade average. With university undergraduates, the same story of poor tuition was compounded by confusing and sometimes downright opaque assessment practices combined with a sink or swim attitude by the universities, which had already taken 3 years of fees. It confirmed his experiences of helping his friends' children cope with the same problems. With postgraduates, the problem was very different - generally he was asked to write their theses. These problems led to him withdrawing from private tuition.

In discussing this with parents, one issue that arises is that students are considered to be adults, and therefore (usually for reasons of data protection), parents are excluded from involvement in decisions about courses and more important from interacting with faculty, even if the student desires it and even if the parents are paying for or underwriting some aspects of the finance (unless a formal disclosure agreement is put in place). For example, for a normal 3-year degree, a student starting in 2012 might accumulate around $£ 53000$ of debt, following the recent fee increase, a doubling of the previous year's figure. ${ }^{4}$ In the United States, lawyers and doctors typically leave college with US $\$ 250000$ debt but expect their university education to set them on a route through 
employment that allows them to repay this in the first few years of high-paid work. This puts them in a vulnerable position in their relationships with universities, and also may put them in dubious moral positions as regards their employment choices and their behaviour during employment. ${ }^{5}$

\section{BACKGROUND}

In the last three decades, higher education has grown rapidly as an industry, all over the world. From being an industry designed to serve the educational needs of the elite in the early 1960s - usually around 5-7 per cent of the population universities have become factories for turning out graduates and postgraduates, serving the needs of around 40-50 per cent of the population in most developed and many rapidly developing nations.

Universities were once institutions where the preservation and development of knowledge was treasured - though every so often they have shown their propensity to sink into the mire of politics and bad faith, with perhaps the worst case of this being the behaviour of some universities in Nazi Germany. ${ }^{6}$ Nonetheless, the general reputation of university academics has remained good, particularly at a time when that of formerly honoured professions such as banking has plummeted. This is despite recent scandals. In Germany, Karl-Theodor zu Guttenberg, a former Minister of Defence, and Silvana Koch-Mehrin, a Vice-President of the European Parliament, resigned after plagiarism was found in their doctoral dissertations. The London School of Economics had to deal with alleged plagiarism in the $\mathrm{PhD}$ thesis of Saif el-Islam Gaddafi, the son of Muhamar Gaddafi, while the head of the school Howard Davies resigned after revelation of the School's links with the regime. ${ }^{7}$ In Pakistan, more than 140 lawmakers were found to have fake degrees. In the United Kingdom, a university registrar was condemned to a suspended jail sentence after he was discovered trading fake degrees for spanking sessions.

In our view, and those of many commentators such as Molesworth, universities have become self-serving, marketised, institutions, where students who pay increasingly high fees are subject to increasingly poor teaching and declining quality standards. ${ }^{8}$ The marketisation of universities has been the focus of much serious study, all over the world, and the conclusions are as expected. Marketised universities - ones that depend increasingly for funding on student fees and grants from a wide range of organisations behave as you would expect, but with one exception. They do not admit that their quality has been compromised in many ways, and in general pay lip service to student as customers, preferring instead to manipulate the student experience and student feedback to maximise their future revenue earning opportunities.

This is despite strong evidence that in many areas, universities' top priority is to 'get the fees in', even to the extent of admitting unsuitable candidates who are unlikely to complete their degrees - a common practice in postgraduate studies and distinctly unethical. A very recent article in The Daily Telegraph identifies a particular example of this practice, citing an e-mail linked to the Times Higher Education Supplement, and is worth quoting at length: ${ }^{9}$

\footnotetext{
Birmingham - a member of the elite Russell Group - came under fire when it emerged a senior don had emailed colleagues telling them to go to desperate lengths to enrol large numbers of lucrative postgraduates. Professor Helen Beebee, head of Birmingham's school of philosophy, theology and religion, said more students were needed to avoid being fined by the university for under-recruiting. In the memo, she urged staff to be 'VERY generous' when assessing applications from postgraduate students, suggesting
} 
candidates should be given places even if they are not totally up to the demands of the course. The comments will fuel concerns that universities are being forced to give special treatment to postgraduate and foreign students - who pay far more than British undergraduates - to boost their income. Most postgraduates at Birmingham can expect to pay at least $£ 4650$ from September, rising to $£ 15660$ for foreign postgraduate students.

Meanwhile, 'difficult' subjects are gradually being removed from the curriculum, literacy is declining among students and lecturers, and - most importantly of all students now receive this clear message from universities, "If you want to get a good degree, chose subjects where you feel you can manage the assessment or where re-sits are allowed, learn how to manage anti-plagiarism software by putting other people's ideas into your own words, do not expect to get much time from your lecturers, whom we appoint primarily for the quality of their research - and who are under extreme pressure to continue performing well in research, whatever this means for teaching quality, and learn how to teach yourself. Most important of all, in student surveys, do not criticise our university, because this will devalue the brand that you will carry for the rest of your life'.

Of course, this is a little extreme. However, this behaviour by academic institutions is only the outcome to be expected, given the funding and other pressures that have been applied to universities. 'Publish or be damned' has been modified into 'Publish $5^{\star}$ or be damned'. In the United Kingdom, the ex-polytechnics, which used to pride themselves on their work in teaching middle-ability students, staffed as they were by lecturers whose whole career depended on teaching, have fallen between the two stools of research and teaching excellence. Many of their staff aspire to join 'proper universities', where they will be able to teach many fewer hours and attempt to publish in $5^{\star}$ journals, no matter how arcane their publications. One of our most distinguished marketing professors, Michael Baker comments on the impact of this on the content of journals:

While there is a complex formula for measurement of research productivity, there can be little doubt that it has been distorted towards a single metric - publication in 'top' journals. So, despite repeated injunctions by the funding authorities that the impact of a piece of research should not be judged solely on the number of citations it receives in other learned journals, but that it should reflect the application of research findings in practice, so far this appears to have had little effect on the evaluation of research output. ${ }^{10}$

His words have been echoed by another distinguished marketing professor, Malcolm McDonald. He pointed out that only 4 per cent of the articles in the two foremost $5^{\star}$ academic journals addressed the top 10 issues of concern to practitioners. ${ }^{11}$

Students are not stupid. Nor are their parents. Many of them sense something is wrong, particularly when their children embark on courses that have been rated highly on quality and bring back tales of incompetent, unintelligible and inaccessible lecturers, stultifying and incompetent bureaucracy and class sizes (even at postgraduate level) that would disgrace the most resource-constrained state schools. Students taking courses involving periods in industry are often shocked by the shoddiness of the placement mechanism and how weak the links are between universities and industry.

What we see is the simple result of basic economic incentives - as behavioural economics has taught us. Individuals will tend to do what benefits them rather than worrying about the consequences, whether for their colleagues, their customers, businesses, public organisations or society in general. In terms of welfare economics, 
if free-riding pays, individuals will tend to do it, unless they have values that prevent them. For us, the lesson is clear. The first big institution they come into contact with preaches one ideal and follows another. Their top two priorities are money and research, while students come a poor third. Universities beckon students to come and learn, but are actually institutions primarily for maximising career opportunities for their staff, who teach decreasing hours and vie for promotion. In other words, universities are free-riding at students' expense. In response to this evident bad faith, many students are responding by learning how to free-ride in return.

In this article, we document the many forms of corruption that take place in universities. The reader might ask why this is this relevant to a marketing journal. The answer is that students are your future customers, who have learnt some ways of wresting what they need from recalcitrant large organisations. If you want them to trust you and engage with you, you need to have a much better process for doing it than universities. You might be able to learn from how the universities are failing to deal with the tensions of combining ethics with performance, and what customer/student management strategies they follow. For universities who have a genuine interest in serving students well, this article shows the obstacles that you face.

We hope that this article will be read by students, so that they will learn about the relevant coping strategies. Of course, we are not relying on this, and the authors are working with the editor of this journal on a plan to produce a book to help students develop their own coping strategies. As they are both at or near retirement, they can do so without the fear of the fate that often befalls university staff who confront universities with their failings. $^{12}$

\section{THE EVIDENCE}

So what is the evidence? Not trusting our own judgement (scepticism was critical to this venture), we decided to carry out a wide-ranging literature search. After several days of browsing our university libraries, we had accumulated around 140 academic articles and three extensive stand-alone bibliographies (as well as the substantial bibliographies attached to many of the articles), not to mention 60 web-based articles. As we had been given a tough deadline by the editor of this journal, we decided to call a halt to our browsing, particularly since new browses were yielding diminishing returns, with very few new articles.

One of the most interesting points about our search results is that they included results from most developed countries, as well as developing countries, covering virtually every topic in the below list. The research also yielded many articles that related to general corruption in local and central governments and the private sector. We do not cite these latter articles here, but suggest that the corruption visible in universities is just part of a wider corruption in which governments pay lip service to ideals and civil servants respond to governments' intentions with policies designed to achieve the desired top-line result without concern for whether it results in unacceptable societal changes. This corruption extends even to immigration policies, where government are now struggling to resolve the problem that they have caused themselves by allowing post-study visas freely to students from countries whose immigration they are trying to halt. ${ }^{13}$

We have not provided a full conventional literature review here because we think that would not serve the purpose of this article. Those who want to read further on this subject are welcome to e-mail us for further bibliographical information. Instead, we have provided 
examples of the most significant results, whether in terms of quantitative or qualitative findings. Before documenting this, we thought it would be worthwhile listing the areas where we found useful results (see Table 1). We have not covered all of these areas in this article, because they are not all relevant to the central thesis of how students are managed and how they respond. However, what this table shows is the systematic nature of the problem. Note that the table is arranged alphabetically by topic, as many issues overlap so a more rational grouping is difficult.

Here are our main conclusions from our review of the literature.

\section{GENERAL EVIDENCE OF DISHONESTY}

Many writers have focused on the general question of corruption and the

Table 1: Examples of issues involving corruption and doubtful ethics in universities

\begin{tabular}{|c|c|}
\hline Sources of corruption & Examples \\
\hline Academic journals & $\begin{array}{l}\text { Favoured submissions } \\
\text { Poor quality of refereeing } \\
\text { Insiders club of top journals } \\
\text { Fake addition of senior names to article author list } \\
\text { Suppression of junior names } \\
\text { Pressures on editors to publish }\end{array}$ \\
\hline Access & $\begin{array}{l}\text { Fixing of access exams/scholarships } \\
\text { Favouring applicants from particular schools } \\
\text { Favouring royal or well-connected families, sports stars, celebrities or rich/ } \\
\text { influential people/politicians or cronies } \\
\text { Offering high-paid non-existent summer jobs to athletes } \\
\text { Collusion of schools with staff and administrators } \\
\text { Favouring students and their families who are compliant with regimes } \\
\text { Students faking CVs, references and qualifications to gain entry }\end{array}$ \\
\hline Administrator behaviour & $\begin{array}{l}\text { Bribes/unofficial fees for favoured access to administrative services and } \\
\text { information or access to student housing/particular dormitories }\end{array}$ \\
\hline Bought grades and degrees & $\begin{array}{l}\text { At all levels, from undergraduate to doctorates } \\
\text { Degree and diploma mills } \\
\text { Elites buying degrees for favoured children } \\
\text { Sexual favours given in exchange for grades } \\
\text { Pressurising students into buying private tuition in exchange for grade guarantees } \\
\text { Conferring honorary degrees and professorial titles in exchange for political } \\
\quad \text { favours and funding }\end{array}$ \\
\hline Drugs on campus & $\begin{array}{l}\text { General tolerance of drugs } \\
\text { Performance enhancing drugs for sports stars }\end{array}$ \\
\hline Employers and senior staff & $\begin{array}{l}\text { Manipulating standards indicators } \\
\text { Selective student recruitment to obtain high ratings } \\
\text { Reflection of general corruption in society, industry and government } \\
\text { Spread of corruption among staff, corruption networks } \\
\text { Failure of boards and senates to exercise governance } \\
\text { Collusion with student unions to cover up problems }\end{array}$ \\
\hline Financial & $\begin{array}{l}\text { Favoured suppliers for investment in campus facilities and student } \\
\text { accommodation, in exchange for incentives } \\
\text { Favoured IT suppliers in exchange for incentives } \\
\text { Favoured banking suppliers in exchange for incentives } \\
\text { Financial directors gambling with university funds } \\
\text { Accepting bribes or sponsorship from other suppliers in exchange for contracts }\end{array}$ \\
\hline Foreign student fees & Setting fees to attract large numbers irrespective of quality \\
\hline Local authorities/government & $\begin{array}{l}\text { Providing incentives to local authorities in exchange for planning permission, for } \\
\text { example for site development, student accommodation } \\
\text { Providing honorary degrees/titles in exchange for government favouritism }\end{array}$ \\
\hline
\end{tabular}


Table 1 continued

\begin{tabular}{|c|c|}
\hline Sources of corruption & Examples \\
\hline Plagiarism and cheating & $\begin{array}{l}\text { Incidence of and acceptance of this } \\
\text { Students buying ghost-written essays } \\
\text { Failure to enforce academic code of conduct } \\
\text { Accepting plagiarism for financial reasons (student fees) }\end{array}$ \\
\hline $\begin{array}{l}\text { Quality management and } \\
\text { falsification }\end{array}$ & $\begin{array}{l}\text { Poor lecturing } \\
\text { Dumbing down of syllabus } \\
\text { Window dressing during inspections } \\
\text { Unclear assessment criteria } \\
\text { Encouraging students to over-rate institution in student satisfaction surveys as } \\
\text { they will carry the brand } \\
\text { Selling examination information } \\
\text { Adversity to and discouragement of whistle blowing } \\
\text { Misrepresentation of quality and other statistics } \\
\text { Manipulating a lecturer's low exam marks by senior staff in order to fit the desired } \\
\text { grade profile without regard to the quality of the exam scripts } \\
\text { Pressuring staff to be more generous in their marking } \\
\text { Being over generous in marking to enhance student satisfaction } \\
\text { Selective presentation of academic performance and job placement data } \\
\text { Failure to manage quality as claimed } \\
\text { Failure to update teaching material } \\
\text { Recommendation of own textbooks to maximise personal income }\end{array}$ \\
\hline Research & $\begin{array}{l}\text { Skimming of research funds (and other funds) } \\
\text { Commercial funding to get biased results } \\
\text { Allocation of government funding by government committees that are 'stitched } \\
\text { up' or old boys clubs } \\
\text { Falsification of results to achieve publication } \\
\text { Green/whitewashing companies }\end{array}$ \\
\hline Sponsoring & Sponsoring of institutes and chairs to get inappropriate PR \\
\hline Staff management & $\begin{array}{l}\text { Professorial or institutional favouritism towards particular staff } \\
\text { Bribes to obtain posts } \\
\text { Falsification of CVs to gain promotion or to gain validation for courses } \\
\text { Representing staff as employed and contributing to university when they are not } \\
\text { Bonuses for making money/covering up }\end{array}$ \\
\hline Visas & Providing easy entry for staff or students with no intention of staying at institution \\
\hline
\end{tabular}

obstacles to academic integrity that have been institutionalised. ${ }^{14}$ In 2007, Osipian concluded that at the time of writing, corruption in higher education was a newly emerging topic in the field of education. ${ }^{15}$ He cited work that had appeared up until then, arguing that scholarly work on corruption in higher education was lacking while the problem itself was significant. In our view, this gap has now been filled, though the implications for this corruption have not been fully understood. He argued that the negative impact of higher-education corruption on economic development and social cohesion was disturbing, and that with the rapid internationalisation of higher education and the growing volume of trade in educational services, matters of educational credentials - and credibility in general were becoming ever more important. $\mathrm{He}$ concluded that the three main areas of fraud were access, quality and equity, that these issues were universal and at stake in every nation, and that corruption affected all three issues, having a negative impact on the quality of higher education and other services, increasing inequality of access to higher education, and causing inequities.

In their work focusing on the accounting profession, Burke et al investigate the origins of the lack of ethical conduct that was clearly visible in corporate scandals such as the Enron and WorldCom and Tyco International scandals. ${ }^{16}$ They point out that many of the corporate executives 
involved in the fraudulent acts were trained in some of the most prestigious US universities. They suggest that the process may begin at universities, as revealed in a number of other articles, such as Nonis and Swift ${ }^{17}$ and Sims, ${ }^{18}$ which found that students who committed acts of academic dishonesty in college were more likely to engage in unethical acts in the business environment.

Chen and Tang examined business and psychology students' attitude toward unethical behaviour and their propensity to engage in unethical behaviour. ${ }^{19}$ They used a 15-item Unethical Behaviour measure with five factors: Abuse Resources, Not Whistle Blowing, Theft, Corruption and Deception. Their results suggested that male students had stronger unethical attitudes and had a higher propensity to engage in unethical behaviour.

\section{THE MARKET IN GRADES, DEGREES, TITLES AND DISSERTATIONS}

The widespread faking of qualifications has caused problems all over the world. For example, Brown investigated credential and qualification fraud ${ }^{20}$ and suggests that the growth of this industry is due to the demand for degree qualifications. Increased supply came from virtual universities, distance education deliverers, face-to-face providers, individuals and entities known as diploma mills and degree mills. In a recent legal case, the evidence of a key witness was dismissed because he was shown to have bought a degree. ${ }^{21}$ Traditional higher education providers reengineered their programmes and marketing strategies to fight these new private providers for the student's money. However, as Osipian, in his work on Russian doctorates, suggests, at the other end of the scale, conferring doctorates is not a dissimilar practice, in the sense that the receivers receive benefits of recognition, in exchange for the different kinds of help that they can extend to the conferring university. ${ }^{22}$ This practice for honorary degrees is common worldwide, and although we could not find academic studies of this practice, there were many articles criticising particular awards on the grounds that they were made for political or similar reasons. ${ }^{23}$

The market in dissertations and essays is a very transparent market, in the sense that it is web-based. Apparently, honest sites conceal behind their front-end advertisements for essay-writing services, while others are more over, offering guaranteed plagiarism-free essays. One of the authors was last year approached to write a dissertation for a London Business School MBA student by an agent acting on behalf of the student, who was a senior manager in the Middle Eastern oil industry. The agent approaching him also suggested that he could make a lot of money by setting up such a service to meet the needs of Saudi students.

\section{PLAGIARISM AND CHEATING}

Many of the studies carried out on academic integrity (and the lack of it) date from the 1990s. It is interesting to note that the pressures on students to graduate and their clearly on average lower calibre as higher education has expanded very rapidly, has made the 'need' to cheat much greater. Universities have reacted not only by introducing tougher ethics codes (see for example, but also by the widespread use of anti-plagiarism software). However, at many universities, this has a possible opposite effect. It teaches students that plagiarism is expected of them. Students are instructed on how to avoid scores that indicate plagiarism, by putting other people's ideas into their own words or, best of all, getting someone else to write your work. As the UK House of Commons debate concerning the performance of the Quality Assurance Agency for Higher Education showed, ${ }^{24}$ senior academics admit the lack of defence against essay-writing services. These have become much more widely available via the 
Internet, and their growth is reminiscent of the growth of injury claims legal services stimulated by the drive for volume in personal accident insurance. In management consultancy, ironically, plagiarism this is known as repurposing and generally deemed quite acceptable, provided that copyright or patents are not infringed.

For students, one of the issues is their aim in attending university. Is it just to obtain a qualification, or more specifically to gain improved employment opportunities, or is the learning and development opportunity, or some combination of these. Of course, students may not have worked all this out - they may be attending university because it has become the automatic next step after school for them and their peers, or even because they cannot find employment - though this might be a reflection of their qualifications before attending university.

That the problem is widespread is fairly clear. Teixeiras carried out a cross-country study on the determinants of economics and business undergraduate cheating that involves 7213 students in 21 countries from the American (4), European (14), Africa (2) and Oceania (1) continents and 7213 students. ${ }^{25}$ She found that the average magnitude of copying among the economics and business undergraduates was quite high (62 per cent) but with a significant cross-country differences. She suggested that average cheating propensity in academia is significantly correlated with 'real world' business corruption.

In Canada, up to 75 per cent of university students have cheated or plagiarised during their academic career. A study from the Canadian Council on Learning, Liars, Fraudsters and Cheats, took data from a 2006 survey of 20000 first-year students at 11 Canadian postsecondary institutions. ${ }^{26}$ Over 50 per cent of students admitted to cheating with 53 per cent confessing to committing one or more acts of plagiarism on written work and 18 per cent admitting to serious cheating during tests and exams in university - serious cheating is defined as copying from another student, helping another student cheat or using notes. Seventy-three per cent of first-year students polled admitted to one or more acts of cheating in high school. Many of these students said they would not consider themselves as cheaters, or labelled their actions as 'trivial cheating'. Cheating among graduate students was rarer, with 35 per cent admitting to cheating on written work and 9 per cent on tests. The University of Waterloo reported an 81 per cent rise in cheating and plagiarism over 2003-2006. Forty-one per cent of faculty surveyed in Canada and the United States admitted to ignoring incidents of suspected academic dishonesty.

Sweden recently published statistics confirming the problem. ${ }^{27}$ The number of students expelled from Sweden's colleges and universities for cheating rose by nearly 50 per cent over 2009-2010. Five hundred and six students were forced to leave Sweden's 26 largest institutions of higher learning last year.

In one of the most famous cases of plagiarism, in 1991 a panel of scholars at Boston University ruled that Dr. King plagiarised parts of his 1952 doctoral dissertation at BU by 'appropriating material from sources not explicitly credited in notes, or mistakenly credited, or credited generally and at some distance in the text from a close paraphrase or verbatim quotation'. An analysis of King's dissertation by Theodore Pappas revealed that over 60 per cent was copied from an earlier dissertation. Clayborne Carson, director of the Martin Luther King, Jr Papers Project, and professor of history at Stanford University, found that King's student essays and published and unpublished addresses and essays all contain 'numerous instances of plagiarism and, more generally, textual appropriation'. ${ }^{28}$ 
The link between unethical behaviour at university and subsequent unethical behaviour in careers has been established in the medical and other professions. For example, a 2005 New England Journal of Medicine paper suggests, for example, that doctors disciplined by state medical boards are three times more likely to have been singled out for unprofessional behaviour while at medical school. A 2001 study of attitudes among business students published in the Journal of Education for Business found that those "who engage in dishonest behaviour in their college classes were more likely to engage in dishonest behaviour on the job'. ${ }^{29}$

However, as has been pointed out, the problem of student plagiarism must not be laid at the door of students. As we in marketing know well, you make your own customers - good or bad. They play by rules that we (at least partly) lay down. As Williams has pointed out, there appears to be an assumption concerning the existence of a culture of academic honesty that is maintained and safeguarded by universities and academia, and into which the academic process aims to socialise students. He quoted research that bemoaned the relative lack of meaningful enquiry into the commercially sensitive and politically charged assumed culture of honesty of academics, despite the established case history of high-profile plagiarism in academia. ${ }^{30}$ Put simply, academics cannot be the pot that calls the student kettle black. One reason for this is what has been happening in research.

\section{FAKING RESEARCH}

However, the problems are not confined to the output of students. The research output of academics has also come into the spotlight. For example, in the United Kingdom in 2011, the House of Commons Science and Technology Committee describes the current state of oversight of research integrity in the United Kingdom as 'highly unsatisfactory'.
This concern is shared in Asia, where scientific research in universities has come under examination. Lee and Schrank ${ }^{31}$ identify the problems of research fraud in North-East Asia caused by liberal research regimes adopted by developmental states and marked by freedom from government oversight, and illiberal laboratory cultures imported from Germany and marked by all-powerful lab directors and their vulnerable underlings. Wu and Dan provide a damning indictment of how the pressures on researchers have led to corruption emerging in relationships with academic journal editors in China. ${ }^{32}$ They state that there is a strong link between corruption in scientific research at colleges and universities and their scientific research evaluation system, which since the 1990s has been increasingly transferred from scientists to administrative departments, whose evaluations focus primarily on the quantity and number of activities and their results. Quality is judged by rankings publishing periodicals and approving departments and units. This method of evaluation also constitutes the main grounds for granting promotions and professional titles. As shown by another author, Gong, editors have become the objects of wooing, favour-currying, connections-seeking and collusions; they have been targeted for attacks, plots and extortion. ${ }^{33}$ Editing and publishing have become avenues for academic irregularities and academic corruption.

Two Chinese academics lost their jobs after an international journal, Acta Crystallographica, revealed scientific frauds, acknowledged by the authors, involving 70 papers, mostly during 2007. ${ }^{34}$ The authors were Doctor Zhong Hua and Professor Liu Tao, both from Jinggangshan University in Jiangxi province. The university fired the two authors and asked Zhong to return 32000 yuan (US\$4700) in incentives. The fraud was discovered during routine testing using checking 
programs, by Ton Spek of the University of Utrecht. The high rate of publications of academic papers by Chinese authors is associated with the drive by the Chinese government to achieve leadership and the associated incentives.

This phenomenon is by no means confined to China. In December 2002, Physics World carried an article titled 'A Very Strange Year' that claimed that 2002 was the 'most tumultuous' year that international physics had known for a long time. ${ }^{35}$ At US Bell Laboratories, J. Hendrik Schön, once regarded as a Nobel Prize candidate, had published more than 100 theses in Science and Nature, and of which 74 had created sensations. However, when various experts conducted a review of his theses, they found that he had faked and doctored experimental data in at least 16 of them. Much evidence has been published about the impact of corporate involvement on the falsification of research results in the United States. ${ }^{36}$ Similar wholesale criticisms of the academic education systems can be sourced not only from all over the Commonwealth of Independent States, but also India. ${ }^{37}$ The failure of senior academics to be wary of dangerous corporate sponsorship likely to lead to biased research was seen recently in the row over Nottingham University's acceptance of significant funding from British American Tobacco for a Centre for Corporate Responsibility. ${ }^{38}$

\section{THE BLACKNESS OF QUALITY ASSESSMENT}

Behind these many specific types of problem may be a failure in quality assessment. A particularly severe case of failure in quality assessment has occurred recently in the United Kingdom, in relation to the Qualifications Assurance Agency for Higher Education (QAA). Charlton and Andras have been among the leading critics of the QAA. ${ }^{39}$ They point out the futility of auditing quality just by examining processes rather than outcomes. As they say, with the QAA,

There was no attempt made to test the assumption that any specific teaching system led to any specific outcome. Instead it was simply assumed that the existence of an explicit and self-consistent system of teaching was synonymous with excellence. By this omission, university teaching quality assurance lost any meaningful link to educational outcomes. By ignoring the connection between processes and outcomes, QAA implicitly chose the criterion of pure, abstract 'auditability' as its benchmark. 'High quality' teaching was defined as that which was comprehensively and self-consistently documented in a closed system. This meant that QAA definition of high quality teaching was an explicit system characterised by Mission Statements, aims and objectives, flowcharts, monitoring, feedback and formal procedures for all imaginable contingencies. ... however the public relations 'spin' of QAA equated this technical definition of teaching quality with the general language usage of 'high quality' which has to do with excellent outcome measures, not system properties.

Most seriously, they explain that

The root of QAA failure can be traced back to a very early stage in the policy implementation. Failure can be blamed upon the way that the legitimate goals of university inspection were first subverted and finally defeated by the public relations aspects of the policy. In other words, the political expediency and media spin concerning the advertised role of QAA, pushed QAA into outright misrepresentation of their function and dishonesty as to what they were doing. In the end, QAA was using a system of quality assurance auditing to try and perform a function which was alien to the capability of the technology.

Both the authors of this article have been involved in such inspections, and can confirm the efforts put into documentation and the fact that inspection of teaching 
quality outcomes never took place on a serious basis, but rather by window-dressed occasional visits to class or interviews with carefully selected students.

The political agenda was clear. The number of students being accepted by UK universities was growing very fast, and the quality needed to be managed down accordingly, to fulfil the nation's requirement for a much larger number of people who were better qualified than if they had only gone to school but not so well qualified as if they had been at an elite university. As Charlton and Andras point out, the function of a national quality assurance scheme should have been to oversee this reduction in standards, and to ensure that the quality reduction did not go further than was needed to achieve much higher rates of graduation. However, as they point out, the QAA said it was increasing academic standards, explicitly by improving teaching, and this meant that there was a fundamental dishonesty involved in the QAA mission. This led to further dishonesties, such as the claim that QAA auditable systems of teaching were intrinsically superior to non-auditable teaching methods.

As those who have been involved in such inspection know, procedures and measures were complex and noncomparable between institutions. Charlton and Andras state that instead of measuring and publishing simple, clear-cut and comprehensible proxy measures of selectivity and provision, such as average A-level grades and staff-student ratios, the QAA published scores derived from aggregating many opaque, irrational, intangible and subjective variables, hiding the quality fall and poorer per capita provision. Most marks related to completeness and consistency of an un-checkably vast amount of paper documentation (for instance there were 17 headings and 64 separate documentation demands relating just to student assessment), some marks were given for non-randomly selected and pre-warned demonstrations of classroom teaching, some following interviews with non-randomly selected groups of graduates and so on. All these were weighted and combined in an unvalidated fashion. The outcome was that the QAA grades were non-transparent and non-objective. Charlton and Andras conclude that the most significant damage inflicted by the QAA was not resources wasted but the institutionalisation of dishonesty in higher education, the culture of cynicism, and the permeation of the system with misinformation that prevents good decisionmaking. ${ }^{40}$

The international ISO 9000 Quality Management standard has also been subjected to similar criticism, and as the quality approach of the QAA is in some senses the intellectual child of ISO 9000, it is worth considering what has been said about this. John Seddon is one the Standard's most outspoken critics. Writing in the Daily Telegraph, Seddon said:

The Standard had a plausible ring to it: write down what you do such that an external inspector can see whether you do as you say and this will form a guarantee to your customers. It spawned inspections agencies ('certification' bodies) that have grown by leaps and bounds in parallel with uptake of the Standard. Growth has been perpetuated by the Standard itself; it encourages users to insist their suppliers do the same. It has been a pyramidal sale of unprecedented scale .... Without market-place coercion ISO 9000 would have withered long ago, for it has little inherent value. The problems are deeper than the madness portrayed in early reports (Oxford City Council insisting Morris Dancers get registered to ISO 9000), the Standard contains bad management theory. It is about as far from the 'Japanese miracle' as it is possible to get .... Toyota, the home of the 'Japanese miracle' tried ISO 9000 in one of its factories and 
promptly ceased its use for they found it to be of no value. The Toyota system represents a fundamentally different way of thinking about the design and management of work. It remains the first challenge to 'command and control' management thinking and it remains beyond the knowledge of most managers. Rather than introducing managers to the secrets of the 'Japanese miracle', ISO 9000 has maintained and exacerbated management traditions that are the reason for our lagging behind. ${ }^{41}$

His article provoked a vigorous response by Stevan Breeze, chief executive of the British Standards Institute. ${ }^{42}$ An open letter from Seddon to Breeze included the following questions:

How has it been possible to assess 51250 firms in one calendar year (a rate of 200 per business day) and have all of them 'pass' without the accreditation process being utterly corrupt and/or lacking in credibility? Was this the biggest rubber-stamping exercise in history? It is said ISO 9000 might be hard to get but it is even harder to lose; it is in the interests of the certification bodies to keep their clients.

It is hard not to draw parallels between the failure of the QAA and ISO 9000. Real quality embraces much more than writing down what you do. According to the Chartered Quality Institute, 'Quality management is an organisation-wide approach to understanding precisely what customers need and consistently delivering accurate solutions within budget, on time and with the minimum loss to society'. ${ }^{43}$ In other words, quality is a question of delivery of what is needed by customers, not of documenting processes. We can be certain that Dr W. Edwards Deming, the father of the Japanese quality revolution would have strongly disapproved of the QAA view of quality. At one of his 4-day seminars he had this to say about ISO 9000, 'ISO 9000 shows a lack of brains'. 44

\section{SPORTS}

We made a minor diversion into this area because it shows what happens when big money is involved, as it is of course in the United States. Here, evidence of preferential admissions irrespective of academic standards reached, and of assignments being written for university sports stars, whether by agents or the university's own faculty. As Ridpath confirms, the subject of academic corruption in intercollegiate athletics has been of significant concern and empirical inquiry for over 100 years. ${ }^{45}$ A particularly serious case was the writing of assignments for students by members of staff at the University of Minnesota, in which 'friendly faculty' looked the other way while Minnesota basketball players turned in 400 papers allegedly written for them by a university staffer. ${ }^{46}$ There are many character and ethical issues that pervade intercollegiate athletics such as academic fraud, cheating in recruiting, sense of entitlements, illegal inducements from boosters, and academic fraud. Ridpath argues that many of these problems cannot be solved without changing the culture of academics and academic integrity.

\section{CONCLUSIONS}

The above represents just a small sample of the articles we reviewed. Of course, they do not prove that all universities are corrupt all the time, nor that if corruption does exist that it is necessarily conscious, nor that what happens in universities is different in kind or degree from what happens in any large organisation in industry or in the public sector. However, they do show that most students are likely to have encountered (whether they realise it or not) some of the consequences of corruption and deception. They also show that, whether in response to this or because they have discovered that it is possible, many students use their own unethical strategies to gain their qualifications. 
This finding created a dilemma for us. Both your authors are strongly in favour of the idea of students as customers, perhaps because we have taught marketing all our lives. By this, we do not mean that 'the customer is always right'. Instead, we mean that 'the student has the same rights and responsibilities as customers'. We have emboldened 'responsibilities' because we believe that in order to get the best from their suppliers, customers do need to 'follow the script', by doing their due diligence to find out what they need to do to get the best and by putting their learning into practice. They gain their rights by observing their responsibilities. The customer is not always right. However, what should they do when they discover that the supplier is lying to them, as the many customers who bought Payment Protection Insurance discovered? They were lied to because they were told they needed it when they did not. The question is not what they should do now, but what one would have advised such customers to do when faced with a sales person suggesting that they needed it when they did not. The obvious strategy would be to minimise risks of not being able to pay, as these risks were being exaggerated by the sales person.

\section{IMPLICATIONS FOR STUDENTS}

What should we advise university students to do? Of course, the sins of the higher education sector outlined above do not all affect students directly, but most of them do, creating situations in which students get poor value for money, by receiving poor teaching (quality and quantity), inappropriate assessment, poor facilities and so on, while being assured that their university performs well in these areas. Individual students may also suffer, whereas others around them do not, for example if they are allocated a poor research supervisor. Poor quality teaching comes in another form, namely highly qualified lecturers with $\mathrm{PhDs}$ who have a poor command of the English language or very strong foreign accents that simply cannot be understood, sometimes combined with a very narrow academic education that prevents competent teaching of broad undergraduate modules. Research qualifications often come before ability to teach and communicate clearly to students.

Worse, once students have made their commitment to an institution, they are trapped. They have no exit. Changing institutions is still very difficult, even with modular and transfer schemes in place. Worse still, their 'voice' (in the United Kingdom, the National Student Survey), results in them blackening the university whose name they carry for the rest of their life, so they do not use it. They are even told this by lecturers. ${ }^{47}$ Stupidly, the survey is administered to final year students, for whom any action based on the results would be too late, rather than early on in their career as students and throughout it, when their feedback might produce results from which they would benefit.

Therefore, in defence of student-customers, our conclusion is that the only ethical way forward for us is to give students the tools to determine whether their university has been cheating them, and if they determine that it has, to consider repaying the university in kind, not through spite, but to facilitate their progress to their objective. How they should do this will be the subject of a future publication. It will include issues such as:

- How to assess whether you are being financially exploited, in terms of the resources you invest versus the resources deployed on your courses, what the consequences of this are likely to be, and what you can do about it by raising it within the university and in public.

- How to identify whether your university is following a deliberate policy of crosssubsiding by appointing lower cost teaching staff with nor research aspirations 
to teach big courses, yielding revenue to subsidise parasitical researchers.

- How to determine whether the lecturers who lecture to you are competent teachers and responsive helpers, and if not, what you can do about it by revealing the problems within the university and in public.

- How to find out whether the researches of the lecturers who teach you have any bearing on what you are taught (as is so often claimed) or indeed on anything in the real world (if that is appropriate), and how you might be able to persuade departments to change their staff recruitment policies.

- How to determine whether the lecturers who teach you have genuine, deep and broad expertise in the subjects they are teaching you and that the job is not being delegated to low cost $\mathrm{PhD}$ students.

- How to find out whether the assessment strategies used are appropriate to what you have been taught, and whether they are implemented with care and appropriate standardisation of marking, and if not, what you can do about it by raising the issue within the university and in public.

- How to identify the quality of the resource allocation processes of the departments who manage you, and to see whether lecturing, supervision and pastoral care resources are allocated according to skills rather than just by numbers.

- How to decide what level of direct help to get, given how the university treats you. This direct help varies from getting advice on assessments and dissertations to getting assignments and dissertations written for you, given how the university treats you.

- How to discover whether members of staff who teach you have plagiarised, and whether that plagiarism has been concealed.

- How to discover whether you can improve your own knowledge as well as your grades by getting direct help, and how to do it.
- How to determine whether your local or national student unions are doing their job of representing your interests as students and customers, or whether they have become involved in the same search for privileges and status as the university staff.

For companies, the conclusion is clear. Many of your customers who have been to university have learnt to play a cynical game. If you try to play the same kind of game with them, particularly lying about quality, you will reap the whirlwind. The same will apply if you employ them and encourage them in the kind of dubious practices that brought down Enron. You are more likely to succeed with this in the short term, but remember that wise and cynical former students at least have an exit here!

\section{REFERENCES AND NOTES}

1 Stone, M. (1999a) Managing good \& bad customers, part 1. Journal of Database Marketing 6(3): 222-232.

2 Stone, M. (1999b) Managing good \& bad customers, part 2. Journal of Database Marketing 6(4): 299-314.

3 Stone, M., Chalder, M. and Gamble, P. (2000) Managing good \& bad customers in practice. Journal of Database Marketing 7(4): 356-380.

4 See http://www.bbc.co.uk/news/education-14488312, accessed 12 August 2011.

5 Many thanks to Bryan Foss for pointing this out, and for making many other useful comments on earlier drafts of this article.

6 For a historical perspective, see Osipian, A. (2004) Corruption as a Legacy of the Medieval University: Financial Affairs. Nashville, TN: Vanderbilt University.

7 For more on British universities' links with the Libyan regime and other suspect organisations, see http://www.guardian.co.uk/uk/2011/mar/14/ gaddafi-regime-university-links-under-scrutiny\#box, accessed 7 August 2011.

8 The best short introduction to the topic of higher education marketisation is Molesworth, M. Nixon, E. and Scullion, R. (2009) Having, being and higher education: The marketisation of the university and the transformation of the student into consumer. Teaching in Higher Education 14(3): 277-287, See also Stephen Newman, S. and Jahdi, K. (2009) Marketisation of education: Marketing, rhetoric and reality. Journal of Further and Higher Education 33(1): 1-11. To read further into this subject, see Molesworth, M., Scullion, R. and Nixon, E. (2010) The Marketisation of Higher Education: The Student as Consumer, Routledge. 
9 Paton, G. (2011) University 'cannot be too choosy over postgraduates'. The Daily Telegraph 12 August, http://www.telegraph.co.uk/education/ educationnews/8695968/University-cannot-be-toochoosy-over-postgraduates.html, accessed 12 August 2011. Many other articles have appeared in The Daily Telegraph, on themes as varied as overseas students plagiarising personal statements for their applications, to the rapid rise in the number of first class degrees awarded.

10 Baker, M. (2010) Commentary: Theory, practice and impact in academic marketing research. Journal of Customer Behaviour 9(1): 5-18.

11 McDonald, M. (2003) Marketing died in the last decade. Interactive Marketing 5(2): 145-159.

12 Many universities now have a whistle-blowing code of practice (a simple Google of 'university whistle blower' will reveal many). However, universities are still found to be wanting here, as the recent case of the University of Gloucestershire makes clear - see Gill, J. (2010) Tribunal finds in favour of Gloucestershire whistleblower. Times Higher Education Supplement 1 October, http://www .timeshighereducation.co.uk/story.asp?storycode $=$ 413703, accessed 12 August 2011.

13 For more on the situation in the USA, see Bartlett, T. Fisher, K. and Keller, J. (2011) Little-known colleges exploit visa loopholes to make millions off foreign students. Chronicle of Higher Education 20 March, http://chronicle.com/article/LittleKnown-Colleges-Exploit/126822/, accessed 11 August 2011. In the UK, the 'loophole' is being plugged - see Travis, A. (2011) Visa curbs will cut overseas students by 80000 , says Theresa May, The Guardian 23 March, http://www.guardian .co.uk/education/2011/mar/22/number-foreignstudents-to-be-cut, accessed 7 August 2011.

14 For example, see Martin, B. (2007) Obstacles to Academic Integrity, Proceedings of the 3rd AsiaPacific Conference on Educational Integrity: Creating a Culture of Integrity, University of South Australia, Adelaide, pp. 21-26. Martin agrees that focuses just on student dishonesty is inappropriate, when examples of faculty and administrative failures in integrity are rife.

15 Osipian, A. (2007) Higher Education Corruption in the World Media: Prevalence, Patterns, and Forms, 32nd Annual Conference of the Association for the Study of Higher Education (ASHE), Louisville, Kentucky.

16 Burke, J.A., Polimeni, R.S. and Slavin, N.S. (2007) Academic dishonesty: A crisis on campus - Forging ethical professionals begins in the classroom. The CPA Journal, May, http://www.nysscpa.org/ cpajournal/2007/507/essentials/p58.htm, accessed 11 August 2011.

17 Nonis, S. and Swift, C.O. (2001) An examination of the relationship between academic dishonesty and workplace dishonesty: A multicampus investigation. Journal of Education for Business 7(2): 69-76.

18 Sims, R.L. (1993) The relationship between academic dishonesty and unethical business practices. Journal of Education for Business 68(4): 207-212.
19 Yuh-Jia Chen, Y.-J. and Tang, L.-P. (2006) Attitude toward and propensity to engage in unethical behavior: Measurement invariance across major among university students. Journal of Business Ethics 69(1): 77-93.

20 Brown, G.M. (2006) Degrees of doubt: Legitimate, real and fake qualifications in a global market. Journal of Higher Education Policy and Management 28(1): 71-79.

21 See the case of Joe Galloway, in British Sky Broadcasting vs Electronic Data Systems (EDS), http://www.computerweekly.com/Articles/2010/ 01/27/240096/EDS-witness-39lied39-in-163700mdispute-with.htm, accessed 7 August 2011.

22 Osipian, A.L. (2008) Dissertations for Sale: Corruption in Russia's Doctoral Education. Nashville, TN: Peabody College, Vanderbilt University.

23 For a Nigerian example, see Honour to people who do not deserve it, http://transparencyng.com/index .php?option $=$ com_content $\&$ view $=$ article $\&$ id $=4705$ : honour-to-people-who-dont-deserve-it- \&catid=59: guest\&Itemid=37, accessed 7 August 2011. A simple Google using 'honorary degree corruption fraud award' brings up examples from all over the world. Most are accusations levelled at universities who have given awards to politicians or other figures who have a known history of evildoing or corruption.

24 House of Commons Innovation, Universities, Science and Skills Committee Students and Universities Eleventh Report of Session 2008-2009 Volume I Report, together with formal minutes, The Stationery Office, 2009.

25 Teixeiras, A.A.C. and Rocha, M.F. (2010) Cheating by economics and business undergraduate students: An exploratory international assessment. Higher Education 59(6): 663-701.

26 Canadian Council on Learning. (2010) Liars, fraudsters and cheats: Dealing with the growth of academic dishonesty, http://www.ccl-cca.ca/ CCL/Reports/LessonsinLearning/LinL20100707 AcademicDishonesty.html, accessed 11 August 2011.

27 More cheaters booted from Swedish colleges, The Local 17 January 2011, http://www.thelocal .se/31478/20110117/, accessed 7 August 2011.

28 This section is quoted from Trout, P. (1999) The academic creed in theory and practice. The Montana Professor 9(3), http://mtprof.msun.edu/Fall1999/ creed.html, accessed 7 August 2011.

29 Quoted from Gulli, C. Kohler, N. and Patriquin, N. (2007) The great university cheating scandal, Macleans.ca 9 February, http://www.macleans.ca/ homepage $/$ magazine $/$ article.jsp? content $=20070209_{\text {_ }}$ 174847_6984.

30 Williams, D. (2010) Academic Integrity: Pots and Kettles? The 4th International Plagiarism Conference, Newcastle Upon Tyne.

31 Lee, C.S. and Schrank, A. (2010) Incubating innovation or cultivating corruption? The developmental state and the life sciences in Asia. Social Forces 88(3): 1231-1256. 
32 Wu, X. and Dan, J. (2006) Scientific and ethical reflections on academic corruption in universities: On the science research evaluation system in China's universities. Journal of Nanjing University of Science and Technology 19(3): 77-81.

33 Gong, X. (2006) Academic degradation and the retreat of the editors: Academic irregularities and the spreading of academic corruption from an editor's perspective. Journal of Gansu Radio \& TV University 16(3): 77-81.

34 Academics fired for cases of fraud, http://www .chinadaily.com.cn/china/2009-12/31/content_ 9249583.htm, accessed 7 August 2011.

35 http://physicsworld.com/cws/article/print/16474, accessed 11 August 2011.

36 See Washburn, J. (2011) Academic freedom and the corporate university, Academe Online 97(1), http:// www.auup.org/AAUP/pubsres/academe/2011/JF/ Feat/wash.htm.

37 Ramachandra, D.S. and Srinivas, D.G. (2009) Crass commercialization and corruption of the Indian medical education system and the resultant decay of the Indian Health Education in the last two decades. A case for urgent international review and monitoring. Electronic Physician 1: 9-16, http:// journals.indexcopernicus.com/fulltxt.php?ICID= 897559.

38 Meikle, J. (2001) Professor quits over tobacco firm's £3.8 $\mathrm{m}$ gift to university. The Guardian $18 \mathrm{May}$, http://www.guardian.co.uk/society/2001/may/18/ cancercare, accessed 7 August 2011. For another example of this, see allegations concerning Procter \& Gamble's relationship with Sheffield University in Washburn, J. (2005) Rent-a-Researcher: Did a British University sell out to Procter \& Gamble? 22 December, Slate, http://www.slate.com/ id/2133061/, accessed 11 August 2011.
39 Charlton, B. and Andras, P. (2002) Auditing as a tool of public policy - The misuse of quality assurance techniques in the UK university expansion. European Political Science 2(1): 24-35.

40 For more on the issue of standards, see Brown, R. (2011) Academic standards: The British experience. Change: The Magazine of Higher Learning 43(3): 65-70, For more on the issue of rankings, see Harvey, L. (2008) Rankings of higher education institutions: A critical review. Quality in Higher Education 14(3): 187-207.

41 These checks don't prove anything, http://www .telegraph.co.uk/finance/2885276/These-checksdont-prove-anything.html. Daily Telegraph 13 May 2004, accessed 11 August 2011.

42 Breeze, S. Raise the standard to win worldwide success, Daily Telegraph 205/2004, http://www .telegraph.co.uk/finance/2885860/Raise-thestandard-to-win-worldwide-success.html, accessed 11 August 2010.

43 See http://www.thecqi.org/Knowledge-Hub/ What-is-quality/.

44 http://deming.org/index.cfm?content $=653$.

45 Ridpath, B.D. (2008) Can the faculty reform intercollegiate athletics? A past, present, and future perspective. Journal of Issues in Intercollegiate Athletics 1: 11-25.

46 For more on this, see Wertheim, L.J. and Yaeger, D. (1999) The Passing Game, Sports Illustrated 14 June: 90-102.

47 See for example, http://www.dailymail.co.uk/ news/article-566200/University-lecturers-toldstudents-glowing-reports-risk-s-t-degree-boostleague-table-ranking.html, accessed 7 August 2011. This evidence has been confirmed to the authors verbally by lecturers in other universities, who said that this practice was common at their university. 